\title{
Micropropagation and Establishment of Humulus lupulus L. Plantlets Under Field Conditions at Southern Brazil
}

\author{
M. P. Machado ${ }^{1}$, Erik Nunes Gomes ${ }^{2}$, Felipe Francisco ${ }^{1}$, Andre Felipe Bernert ${ }^{1}$, João Carlos Bespalhok Filho ${ }^{1}$ \\ \& Cícero Deschamps ${ }^{1}$ \\ ${ }^{1}$ Programa de Pós-Graduação em Agronomia Produção Vegetal, Universidade Federal do Paraná, Curitiba, Brazil \\ ${ }^{2}$ Department of Plant Biology and Plant Pathology, Rutgers University, New Brunswick, USA \\ Correspondence: Cícero Deschamps, Departamento de Fitotecnia e Fitossanitarismo, Universidade Federal do \\ Paraná, Rua dos Funcionários, 1540, Curitiba, Brazil. Tel: 55-(41)-3350-5687. E-mail: cicero@ufpr.br
}

Received: April 8, $2018 \quad$ Accepted: May 17, $2018 \quad$ Online Published: June 15, 2018

doi:10.5539/jas.v10n7p275 URL: https://doi.org/10.5539/jas.v10n7p275

\begin{abstract}
Tissue culture technique can be an important approach for the rapid propagation of Humulus lupulus L. (hop plant). The present study evaluated different culture media for hop plants (cv. Columbus) in vitro shoots multiplication, as well as ex vitro rooting and plantlets establishment under field conditions at Southern Brazil. The culture medium containing the plant growth regulator thidiazuron (TDZ) resulted in greater in vitro shoots multiplications (five shoots per explant). For microcuttings ex vitro rooting, indole-3-butyric acid (IBA) application at a concentration of $3000 \mathrm{mg} \mathrm{L}^{-1}$ resulted in higher rooting and survival percentages during acclimatization. After 90 days of acclimatization, the plantlets were transplanted under field conditions and had their development and productivity evaluated 122 days after transplanting. Micropropagated plants achieved $100 \%$ survival under field conditions. Nitrogen supply is highly necessary for hop plants initial development at Southern Brazil. Micropropagation is a viable technique for quality plantlet production of $H$. lupulus cv. Columbus.
\end{abstract}

Keywords: hops, in vitro multiplication, microcutting, acclimatization

\section{Introduction}

Humulus lupulus L. (Cannabaceae) is an herbaceous, dioecious plant species, popularly known as hop plant. The species female inflorescences, named cones or hops, contain lupulin glands, structures producing alpha and beta acids and essential oils. These substances confer remarkable importance to the hops in the brewing industry, since they provide bitterness and aroma to beer (Neve, 1991; Taniguchi et al., 2014).

Currently, the largest hops producing countries are Germany and the United States. Brazil, in turn, is characterized for being a significant importer. In 2010, the country imported 5\% from all hops exported by Germany (Biendl et al., 2014). This outstanding economic potential has brought interest in developing hop plants cultivation with adapted genetic materials for different Brazilian regions. Therefore, germplasm introduction and evaluation is one of the first steps to make this specialty crop economically viable to meet the domestic market demands.

Plant propagation is one of the main limiting factors for introducing a new crop, since the production of quality plantlets is a fundamental feature for success in the subsequent cultivation stages. Commercially, H. lupulus is vegetatively propagated, either by rhizomes segments or herbaceous stem cuttings. Nevertheless, tissue culture techniques can also be useful tools for hop plants multiplication. Some protocols for micropropagation of the species have already been established and proved to be viable (Batista et al., 1996, 2000, 2008).

The ultimate success in plant micropropagation lies in establishing an efficient protocol from in vitro regeneration to acclimatization stage, which is usually different for each species or even for each cultivar. Different culture media have been proposed for H. lupulus in vitro organogenesis. (Roy et al., 2001; Skof et al., 2007; Peredo et al., 2009; Gatica-Arias \& Weber, 2013). Culture media should provide macro and micronutrients, as well as vitamins, carbohydrates and plant growth regulators, necessary for plant regeneration.

Because micropropagation is a high-cost technique, exclusion of the in vitro rooting step can be used, whenever feasible. In Leptadenia reticulata, the depletion of this stage reduced the time and the cost for quality plantlets 
production (Shekhawat et al., 2006). Ex vitro rooting of microcuttings is also a viable alternative for species that present poor rooting rates in regular macropropagation (Machado et al., 2011). However, microcutting techniques must be optimized and adapted to each species or cultivar to increase rooting performance in valuable plant species (Osman et al., 2013). It is also important, when introducing this technique into a new crop or a new region, to evaluate the plantlets performance under field conditions.

Although hop plants tissue culture has proven to be feasibly used for research, breeding and large-scale plantlet production, micropropagation-produced plantlets performance under field conditions has not been reported.

Aiming the establishment of H. lupulus (cv. Columbus) micropropagated plantlets under field conditions, the present study intended to: (i) evaluate different culture media for shoots in vitro multiplication; (ii) promote microcuttings ex vitro rooting; and (iii) evaluate micropropagated plants establishment and initial growth with and without nitrogen application under field conditions at southern Brazil. To the best of our knowledge, the present study is one of the first scientific approaches for the propagation and establishment of commercial hops cultivation in Brazil.

\section{Method}

\subsection{Plant Material}

The explants sources for in vitro culture were 1-year old H. lupulus (cv. Columbus) plants cultivated under greenhouse conditions. The explants consisted of nodal segments approximately $1.0 \mathrm{~cm}$ in length.

\subsection{Culture Media and Shoots Regeneration}

After washed in running tap water, nodal segments were surface-disinfected by submersion in $70 \%(\mathrm{v} / \mathrm{v})$ ethanol for 25 seconds, followed by treatment with $2 \%(\mathrm{v} / \mathrm{v})$ sodium hypochlorite for 20 minutes, and then rinsed three times with autoclave-sterilized deionized water. Following asepsis, the explants were placed in glass flasks $(30 \times$ $80 \mathrm{~mm}$ ) containing $20 \mathrm{~mL}$ of autoclave-sterilized $\left(120{ }^{\circ} \mathrm{C}\right.$ at $1.5 \mathrm{~atm}$ for 20 minutes) MS culture medium (Murashige \& Skoog, 1962).

Shoots about $2.0 \mathrm{~cm}$ in length were isolated from the in vitro established nodal segments and placed in glass flasks (240 mL volume) containing $20 \mathrm{~mL}$ of different culture media. Four culture media previously used in hop plants micropropagation were evaluated: M1-MS medium (Murashige \& Skoog, 1962) plus $30 \mathrm{~g} \mathrm{~L}^{-1}$ sucrose, 100 $\mathrm{mg} \mathrm{L}^{-1}$ myo-inositol and $7 \mathrm{~g} \mathrm{~L}^{-1}$ agar $\left(\right.$ Vetec $^{\circledR}$ ) (Gatica-Arias \& Weber, 2013); M2-MS medium plus vitamins from Gamborg's B5 medium (Gamborg et al., 1968), $20 \mathrm{~g} \mathrm{~L}^{-1}$ glucose, $100 \mathrm{mg} \mathrm{L}^{-1}$ myo-inositol, $1 \mathrm{mg} \mathrm{L}^{-1}$ benzylaminopurine (BAP), and $7 \mathrm{~g} \mathrm{~L}^{-1}$ agar (Vetec ${ }^{\circledR}$ ) (Skof et al., 2007); M3-MS medium plus $20 \mathrm{~g} \mathrm{~L}^{-1}$ glucose, $100 \mathrm{mg} \mathrm{L}^{-1}$ myo-inositol, $4.4 \mathrm{mg} \mathrm{L}^{-1} \mathrm{BAP}, \quad 0.1 \mathrm{mg} \mathrm{L}^{-1}$ calcium pantothenate, $3 \mathrm{~g} \mathrm{~L}^{-1}$ agar $\left(\operatorname{Vetec}^{\mathbb{B}}\right)$ and $1 \mathrm{~g} \mathrm{~L}^{-1}$ GelRite (Šuštar-Vozlič et al., 1999); and M4-MS medium plus $30 \mathrm{~g} \mathrm{~L}^{-1}$ sucrose, $100 \mathrm{mg} \mathrm{L}^{-1}$ myo-inositol, 0.0547 $\mathrm{mg} \mathrm{L}^{-1}$ indoleacetic acid (IAA), $0.2189 \mathrm{mg} \mathrm{L}^{-1}$ thidiazuron (TDZ) and $7 \mathrm{~g} \mathrm{~L}^{-1}$ agar (Vetec ${ }^{\circledR}$ ) (Roy et al., 2001).

All culture were kept in a growth chamber with $25 \pm 2{ }^{\circ} \mathrm{C}$ temperature, 16 -h photoperiod and a photon flux density of $45 \mu \mathrm{mol} \mathrm{m} \mathrm{m}^{-2} \mathrm{~s}^{-1}$.

Two subcultures were performed every 30 days. For the culture media experiment, the following variables were measured: number of new shoots per explant, average number of leaves on new shoots, average new shoots length (height), percentage of rooted shoots and percentage of callus formation on explants. The experimental design was completely randomized, with five replications and 14 explants per plot.

\subsection{Ex vitro Rooting and Acclimatization}

Hop plants in vitro grown shoots were used to make microcuttings approximately $4 \mathrm{~cm}$ long, with two pairs of leaves. Microcuttings had their bases immersed for 10 seconds in hydroalcoholic solutions (50\%) of indole-3-butyric acid (IBA) in the following concentrations: 0 (control); 500; 1000; 2000; 3000 and $4000 \mathrm{mg} \mathrm{L}^{-1}$. After treatments, microcuttings were immediately planted into $120 \mathrm{~cm}^{3}$ plastic tubes containing Tropstrato ${ }^{\circledR}$ commercial substrate (Vida Verde-Tecnologia em Substratos ${ }^{\mathrm{TM}}$, Brazil) and kept in intermittent misting chamber during 15 days. After this period, plants were transferred to a greenhouse with daily manual irrigation.

Greenhouse inside temperature and relative humidity monitoring was performed using a thermo-hygrometer. Mean maximum temperature was $27.38{ }^{\circ} \mathrm{C}$ and mean minimum was $14.12{ }^{\circ} \mathrm{C}$ while the mean maximum humidity was $93.9 \%$ and the mean minimum was $66.9 \%$.

After 42 days from planting, rooting and survival percentages and plantlets aboveground length were measured. The experiment was conducted in a completely randomized design, with four replications and 25 microcuttings per plot. 


\subsection{Plantlets Establishment Under Field Conditions}

At 90 days after acclimatization stage, micropropagated plantlets were transplanted to the field. Plants were spaced $1 \mathrm{~m}$ apart within the rows and the rows were spaced $3 \mathrm{~m}\left(1,333\right.$ plants ha $\left.\mathrm{a}^{-1}\right)$. Hop plants were conducted in a training system with $6 \mathrm{~m}$ height trellis wires. Two baling twines were stretched from the overhead trellis wires to the ground for each plant. The twines were attached to a small stake at the ground level. Four vigorous vines were selected from each plant ( 2 vines per twine). The experimental area was located at the Agraria Foundation for Agricultural Research, an agro-industrial cooperative located in the district of Entre Rios, in Guarapuava city, State of Parana, Brazil.

Soil samples were collected from the experimental area and the results were: $\mathrm{pH}=4.7 ; \mathrm{Al}^{3+}=0.23 \mathrm{cmol}_{\mathrm{c}} \mathrm{dm}^{-3}$; $\mathrm{H}^{+}+\mathrm{Al}^{3+}=7.2 \mathrm{cmol}_{\mathrm{c}} \mathrm{dm}^{-3} ; \mathrm{C}^{2+}=2.9 \mathrm{cmol}_{\mathrm{c}} \mathrm{dm}^{-3} ; \mathrm{Mg}^{2+}=1.3 \mathrm{cmol}_{\mathrm{c}} \mathrm{dm}^{-3} ; \mathrm{K}^{+}=0.22 \mathrm{cmol}_{\mathrm{c}} \mathrm{dm}^{-3} ; \mathrm{P}=7.6 \mathrm{mg} \mathrm{dm}{ }^{-3}$; $\mathrm{C}=26.88 \mathrm{~g} \mathrm{dm}^{-3}$; base saturation $=38.36 \%$. Soil correction was performed according to CQFS (2004) recommendations.

The effects of nitrogen on micropropagated hop plants establishment and initial growth under field conditions was assessed by employing two treatments: T1: application of $30 \mathrm{~kg} \mathrm{~N} \mathrm{ha}^{-1}$; and T2: control treatment without nitrogen. For the treatment with nitrogen, the nutrient source was urea $(45 \% \mathrm{~N})$ and it was applied by sowing at the time of transplanting plantlets into the field. The experiment was performed under a randomized complete block design, with 5 replication and 10 plants per plot.

After 122 days from transplanting into the field, the following variables were measured: dry leaf yield, dry stem yield, dry cone yield, plant length (height) and leaf area. Leaves and cones were separated manually from the stems and subsequently dried at $65{ }^{\circ} \mathrm{C}$ during 48 hours in a dryer with forced air circulation for assessment of cones, leaf and stem dry weight. Plant height was determined by the distance from the ground level to the highest point of the plant on the training twines.

Fifty $0.785 \mathrm{~cm}^{2}$ leaf discs were weighted from each experimental plot and the leaf area was then calculated as proportion of total leaves weight. Following, Physiological indexes were calculated based on these data, as described by Radford (1967). Leaf area index (LAI) was determined by the ratio between leaf area and soil area occupied by the plants (as a function of plant spacing). Leaf area ratio (LAR) was defined as the quotient between the leaf area and plant total dry weight. Specific leaf area (SLA) represents the relation between leaf area and leaf dry weight and, leaf weight ratio (LWR) was calculated by the proportion of leaves dry weight on total plant dry weight.

\subsection{Statistical Analysis}

Data from all experiments were initially submitted to analysis of variances homogeneity by the Bartlett's test. For the experiments with culture media and nitrogen application, the means were compared by the Tukey's Test at 5\% probability. For the ex vitro rooting experiment, polynomial regression analysis was performed. Percentage values (rooting, survival and callus formation) were $\arcsin \sqrt{x / 100}$ transformed before the ANOVA was performed. All analyses were carried out using the statistical software Assistat (Silva \& Azevedo, 2016).

\section{Results}

\subsection{Culture Media and Plant Regeneration}

Differences in culture media exerted significant influence over the analyzed variables. M4 medium promoted the highest number of shoots per explant (approximately 5 shoots per explant), whereas M1 and M3 media showed the lowest number (approximately 1 shoot per explant). The number of leaves on new shoots was also higher in the M4 medium, reaching about 11 leaves per shoot. TDZ-supplemented media was previously reported as promoting higher numbers of leaves and nodes on explants in a micropropagation system developed for $H$. lupulus (Roy et al., 2001). In other species, such as Rauvolfia serpentine, TDZ was also effective in in vitro multiplication (Alatar, 2015).

Regarding shoots length, M1 medium provided the highest values ( $2.7 \mathrm{~cm}$ on average), differing statistically from the other evaluated media. Plants grown on M2 medium showed the lowest shoot length $(1.8 \mathrm{~cm}$ on average) although not statistically different from M3 medium (Table 1). For the $\mathrm{G} \times \mathrm{N} 15$ hybrid (almond tree $\times$ peach tree), it was similarly reported that the highest shoots length in vitro were achieved on culture media without plant growth regulators supplementation, which may be explained mainly by the cytokinin effects on boosting shoots emission, inducing plants to produce a higher number of nutrients sinks with lower individual growth and elongation (Arab et al., 2014). Additionally, cytokinins are known to reduce apical dominance and induce adventitious shoots formation from meristematic explants (Resmi \& Nair, 2011). 
Explants rooting was observed only on M1 and M3 culture media (Table 1). Adventitious shoots and roots formation on in vitro cultivated explants is strongly related to the cytokinin/auxin balance (Su et al., 2011), and, accordingly, it was observed lower shoot multiplication rates on the media that induced rooting.

The highest percentage $(\mathrm{P}<0.05)$ of callus formation on new shoots occurred on M4 medium $(90.2 \%)$. M1 medium induced no callus formation (Table 1). These results are likely to be related to the lack of plant growth regulators on M1 medium and the presence of TDZ in M4 medium. Among the several external factors influencing callus formation in hops tissue culture, plant growth regulators play a fundamental role. It has already been reported that hop plants explants show no callus formation with the absence of these compounds in culture media (Fortes \& Pais, 2000).

Table 1. Number of new shoots per explant, number of leaves on new shoots, new shoots length (height), shoots rooting percentage and callus formation percentage on Humulus lupulus (cv. Columbus) nodal segments in vitro cultivated using different culture media

\begin{tabular}{llllll}
\hline Culture media & Shoots number & Leaves number & Heigth $(\mathrm{cm})$ & Rooting $(\%)$ & Callus (\%) \\
\hline M1 & $1.4 \mathrm{c}$ & $5.8 \mathrm{c}$ & $2.7 \mathrm{a}$ & $32.1 \mathrm{~b}$ & $0.0 \mathrm{~d}$ \\
$\mathrm{M} 2$ & $2.0 \mathrm{~b}$ & $8.1 \mathrm{~b}$ & $1.8 \mathrm{c}$ & $0.0 \mathrm{c}$ & $57.7 \mathrm{~b}$ \\
$\mathrm{M} 3$ & $1.1 \mathrm{c}$ & $4.6 \mathrm{~d}$ & $2.0 \mathrm{bc}$ & $39.0 \mathrm{a}$ & $43.9 \mathrm{c}$ \\
M4 & $5.2 \mathrm{a}$ & $10.8 \mathrm{a}$ & $2.1 \mathrm{~b}$ & $0.0 \mathrm{c}$ & $90.2 \mathrm{a}$ \\
\hline $\mathrm{CV}(\%)$ & 8.57 & 2.04 & 4.45 & 14.78 & 7.37 \\
\hline
\end{tabular}

Note. Means followed by same letter in the column are not statistically different according to Tukey's test $(\mathrm{P}<$ $0.05) . \mathrm{CV}=$ coefficient of variation.

\subsection{Ex vitro Rooting and Acclimatization}

Microcuttings rooting percentages as a function of IBA concentrations were adjusted in a quadratic behavior. The maximum efficiency concentration, reaching about $100 \%$ rooting, was estimated at $2844.8 \mathrm{mg} \mathrm{L}^{-1} \mathrm{IBA}$, according to the regression equation (Figure 1A). In the control treatment, rooting percentage was about $73 \%$. As observed in Prunus serrulata stem cuttings (Fragoso et al., 2017), when endogenous auxin content is insufficient, the application of synthetic auxins like IBA is important to promote a favorable hormonal balance for adventitious rooting promotion. The ideal auxin concentration to be applied exogenously depends on the species being studied. For Passiflora foetida microcuttings, for example, 97\% rooting was obtained at a lower concentration $\left(300 \mathrm{mg} \mathrm{L}^{-1}\right)$ than the ideal one estimated for $H$. lupulus in the present study (Shekhawat et al., 2015).

The relatively high rooting percentage on microcuttings under the control treatment can be explained by the fact that the adventitious rooting in stem cuttings is also strongly influenced by the natural endogenous auxin produced by the leaves and buds, which moves naturally to the cuttings base promoting cells division and differentiation into a new root system (Zuffellato-Ribas \& Rodrigues, 2001; Olatunji et al., 2017).

Plantlets length and survival, similarly to plantletss rooting, were adjusted in quadratic curves according to the IBA concentrations. Maximum survival after 42 days acclimatization was estimated at a concentration of about $2925 \mathrm{mg} \mathrm{L}^{-1}$ IBA (Figure 1B), whereas maximum length $(22.1 \mathrm{~cm})$ is predictable to be achieved at a $2863 \mathrm{mg} \mathrm{L}^{-1}$ IBA concentration (Figure 1C), according to second degree regression equations. Therefore, concentrations about $3000 \mathrm{mg} \mathrm{L}^{-1}$ IBA can be recommended for ex vitro rooting of $H$. lupulus cv. Columbus microcuttings. 

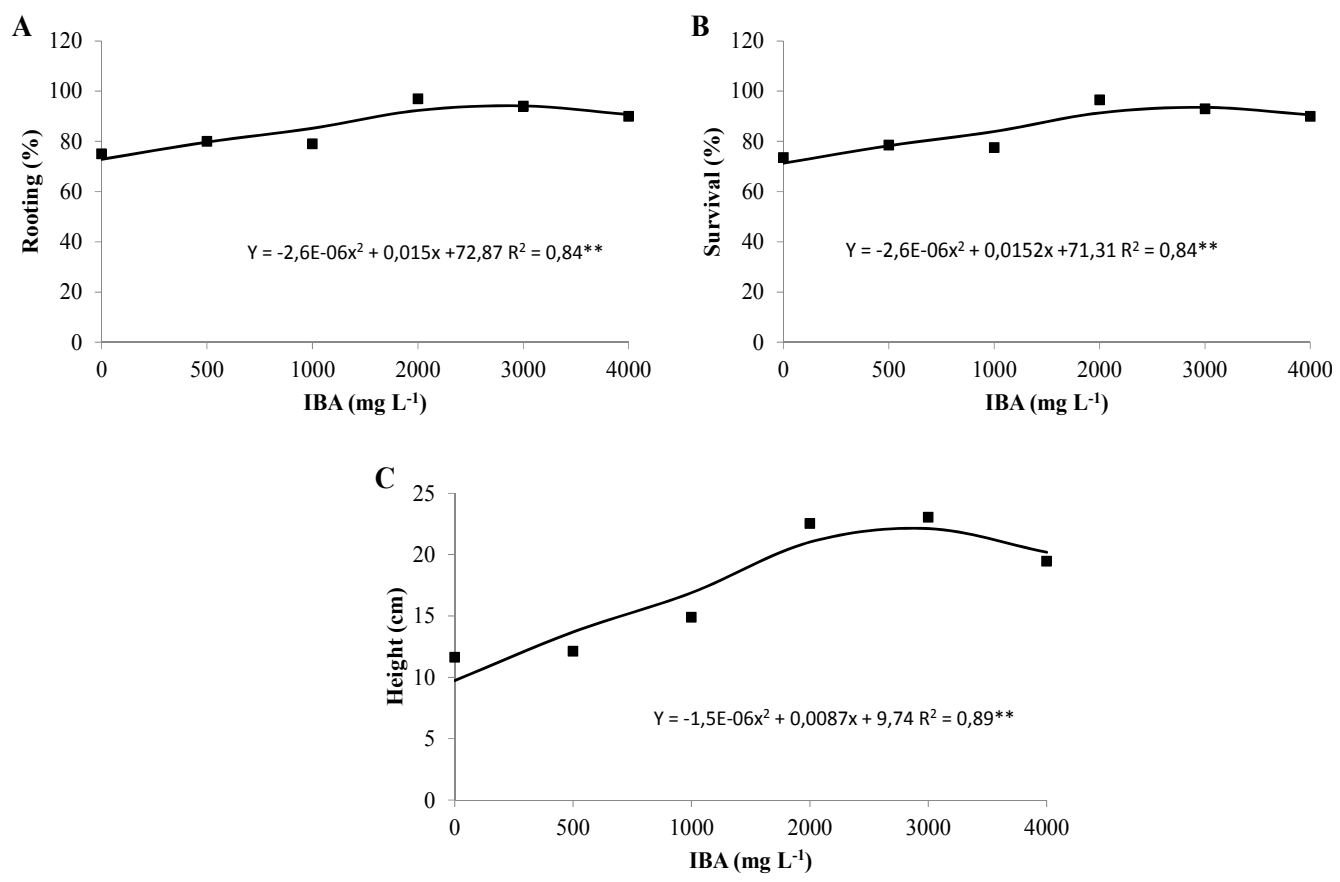

Figure 1. IBA effects on rooting (A) and survival (B) percentages and length (height) (C) of Humulus lupulus cv. Columbus microcuttings after 42 days acclimatizatization

\subsection{Establishment Under Field Conditions}

Although all transplanted plantlets survived, in general, hop plants showed relatively reduced growth, which was expected, as hop production usually only get to its maximum value after three years from planting, when the plants reach their full growth (National Hop Association of England, 2001).

Considering the treatments, plants presented better performance in all variables when nitrogen was applied. When treated with $30 \mathrm{~kg} \mathrm{ha}^{-1} \mathrm{~N}$, plants showed an average dry leaf yield of $138.4 \mathrm{~kg} \mathrm{ha}^{-1}$ compared to $21.9 \mathrm{~kg}$ $\mathrm{ha}^{-1}$ when no nitrogen was applied. Similar behavior was observed for dry stem yield and dry cone yield, which were remarkably higher in plants that received nitrogen. Dry cone yield reached $61.1 \mathrm{~kg} \mathrm{ha}^{-1}$ in the nitrogen-treated plants (Table 2). Previous studies have shown that hop cones yield is highly influenced by nitrogen supply to plants (Bavec et al., 2003). Biomass accumulation is dependent on plant's ability to maximize photosynthesis, which, among other factors, is related to nutritional aspects (Mandal et al., 2013).

As the biomass yields, physiological indices LAI, SLA, LWR and LAR were significantly superior in plants treated with nitrogen at transplanting, evidencing the highest growth of plants (Table 2). Taken together, these indexes represent the quality of plants photosynthetic apparatus and help to explain in terms of light and $\mathrm{CO}_{2}$ harvesting capacity, the better productive performance of nitrogen-supplemented plants.

Table 2. Dry leaf yield, dry stem yield, dry cone yield and physiological indexes from Humulus lupulus cv. Columbus micropropagated plants according to nitrogen presence or absence under fiel conditions. Guarapuava, Paraná State, Brazil

\begin{tabular}{lllllllll}
\hline $\begin{array}{l}\text { Nitrogen } \\
\left(30 \mathrm{~kg} \mathrm{ha}^{-1}\right)\end{array}$ & $\begin{array}{l}\text { DLY } \\
\left(\mathrm{kg} \mathrm{ha}^{-1}\right)\end{array}$ & $\begin{array}{l}\text { DSY } \\
\left(\mathrm{kg} \mathrm{ha}^{-1}\right)\end{array}$ & $\begin{array}{l}\text { DCY } \\
\left(\mathrm{kg} \mathrm{ha}^{-1}\right)\end{array}$ & $\begin{array}{l}\text { Height } \\
(\mathrm{cm})\end{array}$ & LAI & $\begin{array}{l}\text { SLA } \\
\left(\mathrm{cm}^{2} \mathrm{~g}^{-1}\right)\end{array}$ & $\begin{array}{l}\text { LAR } \\
\left(\mathrm{cm}^{2} \mathrm{~g}^{-1}\right)\end{array}$ & LWR \\
\hline Absence & $21.9 \mathrm{~b}$ & $12.3 \mathrm{~b}$ & $4.0 \mathrm{~b}$ & $86.8 \mathrm{~b}$ & $0.027 \mathrm{~b}$ & $125.8 \mathrm{~b}$ & $79.8 \mathrm{~b}$ & $0.640 \mathrm{~b}$ \\
Presence & $138.4 \mathrm{a}$ & $53.8 \mathrm{a}$ & $61.1 \mathrm{a}$ & $228.3 \mathrm{a}$ & $0.219 \mathrm{a}$ & $158.8 \mathrm{a}$ & $114.5 \mathrm{a}$ & $0.721 \mathrm{a}$ \\
\hline CV $(\%)$ & 11.99 & 15.73 & 59.63 & 12.05 & 8.53 & 8.14 & 5.77 & 4.87 \\
\hline
\end{tabular}

Note. Means followed by same letter in the column are not statistically different according to Tukey's test $(\mathrm{P}<$ $0.05)$. DLY = dry leaf yield. DSY = dry stem yield. $\mathrm{DCY}=$ dry cone yield. $\mathrm{LAI}=$ leaf area index. SLA = specific leaf area. $\mathrm{LAR}=$ leaf area ratio. $\mathrm{LWR}=$ leaf weight ratio. $\mathrm{CV}=$ coefficient of variation. 


\section{Conclusions}

M4 culture medium (containing TDZ) provides higher adventitious shoots multiplication rates on in vitro cultivated $H$. lupulus (cv. Columbus) nodal segments. Ex vitro rooting and acclimatization of hop plants microcuttings can be successfully performed using IBA concentrations about $3000 \mathrm{mg} \mathrm{L}^{-1}$. Nitrogen application $\left(30 \mathrm{~kg} \mathrm{ha}^{-1}\right)$ at the time of transplanting plantlets promotes greater development and dry cones yield under Southern Brazil conditions. Micropropagation is a viable technique for quality plantlets production of $H$. lupulus cv. Columbus.

\section{References}

Alatar, A. A. (2015). Thidiazuron induced efficient in vitro multiplication and ex vitro conservation of Rauvolfia serpentine-A potent antihypertensive drug producing plant. Agriculture and Environmental Biotechnology, 29(3), 489-497. https://doi.org/10.1080/13102818.2015.1017535

Arab, M. M., Yadollani, A., Shojaeiyan, A., Shokri, S., \& Ghojah, S. M. (2014). Effects of nutrient media, different cytokinin types and their concentrations on in vitro multiplication of $\mathrm{G} \times \mathrm{N} 15$ (hybrid of almond $\times$ peach) vegetative rootstock. Journal of Genetic Engineering and Biotechnology, 12(2), 81-87. https://doi.org/10.1016/j.jgeb.2014.10.001

Batista, D., Ascensão, L., Sousa, M. J., \& Pais, M. S. (2000). Adventitious shoot mass production of hop (Humulus lupulus L.) var. Eroica in liquid medium from organogenic nodule cultures. Plant Science, 151(1), 47-57. https://doi.org/10.1016/S0168-9452(99)00196-X

Batista, D., Fonseca, S., Serrazina, S., Figueiredo, A., \& Pais, M. S. (2008). Efficient and stable transformation of hop (Humulus lupulus L.) var. Eroica by particle bombardment. Plant Cell Reports, 27(7), 1185-1196. https://doi.org/10.1007/s00299-008-0537-6

Batista, D., Sousa, M. J., \& Pais, M. S. (1996). Plant regeneration from stem and petiole-derived callus of Humulus lupulus L. (hop) clone Bragança and var. Brewers Gold. In Vitro Cell Development Biology Plant, 32(1), 37-41. https://doi.org/10.1007/BF02823011

Bavec, F., Brežnik, Č. B., \& Brežnik, M. (2003). Hop yield evaluation depending on experimental plot area under different nitrogen management. Plant, Soil and Environment, 49(4), 163-167. https://doi.org/ 10.17221/4108-PSE

Biendl, M., Engelhard, A., Forster, A., Gahr, A., Lutz, A., Mitter, W., ... Schönberger, C. (2014). Hops: Their cultivation, composition and usage (1st ed.). Nuremberg: Fachverlag Hans Carl.

CQFS (Comissão de Química e Fertilidade do Solo). (2004). Manual de adubação e calagem para os estados do Rio Grande do Sul e Santa Catarina. Porto Alegre, RS: Sociedade Brasileira de Ciência do Solo-Núcleo Regional Sul.

Fortes, A. M., \& Pais, M. S. (2000). Organogenesis from internode-derived nodules of Humulus lupulus var. Nugget (Cannabinaceae): Histological and changes in the starch content. American Journal of Botany, 87(7), 971-979. https://doi.org/10.2307/2656996

Fragoso, R. O., Stuepp, C. A., Rickli, H. C., Zuffellato-Ribas, K. C., \& Koehler, H. S. (2017). Maximum efficiency concentration of indole butyric acid in promoting the rooting of Japanese Flowering Cherry. Ciência Rural, 47(1), 1-6. https://doi.org/10.1590/0103-8478cr20150894

Gamborg, O. L., Miller, R., \& Ojima, K. (1968). Nutrient requirements of suspension cultures of soybean root cells. Experimental Cell Research, 50(1), 151-158. https://doi.org/10.1016/0014-4827(68)90403-5

Gatica-Arias, A., \& Weber, G. (2013). Genetic transformation of hop (Humulus lupulus L. cv. Tettnanger) by particle bombardment and plant regeneration using a temporary immersion system. In Vitro Cellular \& Developmental Biology-Plant, 49(6), 656-664. https://doi.org/10.1007/s11627-013-9574-0

Machado, M. P., Santos, G. D., Deschamps, C., \& Biasi, L. A. (2011). Enraizamento de microestacas de Lavandula angustifolia. Ciência Rural, 41(5) 767-772. https://doi.org/10.1590/S0103-84782011000500005

Mandal, S., Evelina, H., Giri, B. B., Singha, V. P., \& Kapoor, R. (2013). Arbuscular mycorrhiza enhances the production of stevioside and rebaudioside-A in Stevia rebaudiana via nutritional and non-nutritional mechanisms. Applied Soil Ecology, 72, 187-194. https://doi.org/10.1016/j.apsoil.2013.07.003

Murashige, T., \& Skoog, F. (1962). A revised medium for rapid growth and bio assays with tobacco tissue cultures. Physiologia Plantarum, 15(3), 473-497. https://doi.org/10.1111/j.1399-3054.1962.tb08052.x 
National Hop Association of England. (2001). What is a hop. Retrieved April 8, 2018, from https://www.britishhops.org.uk/hops

Neve, R. A. (1991). Hops. London: Chapman and Hall. https://doi.org/10.1007/978-94-011-3106-3

Olatunji, D., Geelen, D., \& Verstraeten, I. (2017). Control of endogenous auxin levels in plant root development. International Journal of Malecular Sciences, 18(12), 2587-2616. https://doi.org. 10.3390/ijms18122587

Osman, M., Samsudin, N. S., Faruq, G., \& Nezhadahmadi, A. (2013). Factors affecting microcuttings of Stevia using a mist-chamber propagation box. The Scientific World Journal, 2013, Article ID 940201. https://doi.org/10.1155/2013/940201

Peredo, E. L., Revilla, M. Á., \& Arroyo-García, R. (2006). Assessment of genetic and epigenetic variation in hop plants regenerated from sequential subcultures of organogenic calli. Journal of Plant Physiology, 163(10), 1071-1079. https://doi.org/10.1016/j.jplph.2005.09.010

Radford, P. J. (1967). Growth Analysis Formulae-Their Use and Abuse. Crop Science, 7(3), 171-175. https://doi.org/10.2135/cropsci1967.0011183X000700030001x

Resmi, L., \& Nair, A. S. (2011). Differential effect of cytokinins in the micropropagation of diploid and triploid Musa cultivars. International Journal of Integrative Biology, 11(1), 35-38.

Roy, A. T., Leggett, G., \& Koutoulis, A. (2001). Development of a shoot multiplication system for hop (Humulus lupulus L.). In vitro Cellular \& Developmental Biology-Plant, 37(1)79-83. https://doi.org/10.1007/ s11627-001-0015-0

Shekhawat, M. S., Kannan, N., Manokari, M., \& Ravindran, C. P. (2015). In vitro regeneration of shoots and ex vitro rooting of an important medicinal plant Passiflora foetida L. through nodal segment cultures. Journal of Genetic Engineering and Biotechnology, 13(2), 209-214. https://doi.org/10.1016/j.jgeb.2015.08.002

Shekhawat, N. S., Kackar, A., Rathore, M. S., Singh, M., Dagla, H. R., \& Arya, V. (2006). Establishment and economic evaluation of micropropagated Jeewanti (Leptadenia reticulate Wight \& Arn.) plants in field. Natural Product Radiance, 5(4), 311-314.

Silva, F. D. A. S., \& de Azevedo, C. A. V. (2016). The Assistat Software Version 7.7 and its use in the analysis of experimental data. African Journal of Agricultural Research, 11(39), 3733-3740. https://doi.org/10.5897/ AJAR2016.11522

Skof, S., Bohanec, D., Kastelec, D., \& Luthar, Z. (2007). Spontaneous induction of tetraploidy in hop using adventitious shoot regeneration method. Plant Breeding, 126(4), 337-456. https://doi.org/10.1111/ j.1439-0523.2007.01378.x

Su, Y. H., Liu, Y. B., \& Zhang, X. S. (2011). Auxin-cytokinin interaction regulates meristema development. Molecular Plant, 4(4), 616-625. https://doi.org/10.1093/mp/ssr007

Šuštar-Vozlič, J., Javornik, B., \& Bohanec, B. (1999). Studies of somaclonal variation in hop (Humulus lupulus L.). Phyton, 39(3), 283-287.

Taniguchi, Y., Taniguchi, H., Yamada, M., Matsukura, Y., Koizumi, H., Furihata, K., \& Shindo, K. (2014). Analysis of the componentes of hard resin in hops (Humulus lupulus L.) and structural elucidation of their transformation products formed during the brewing process. Journal of Agricultural and Food Chemistry, 62(47), 11602-11612. https://doi.org/10.1021/jf504394h

Zuffellato-Ribas, K. C., \& Rodrigues, J. D. (2001). Estaquia: uma abordagem dos principais aspectos fisiológicos. Curitiba, PR: UFPR.

\section{Copyrights}

Copyright for this article is retained by the author (s), with first publication rights granted to the journal.

This is an open-access article distributed under the terms and conditions of the Creative Commons Attribution license (http://creativecommons.org/licenses/by/4.0/). 